\title{
The Simulation Study of a Restructured Residential Low-Voltage Distribution System Microgrid
}

\author{
L. Ramesha, ${ }^{*}$ and Umamageswarib \\ $a^{a *}$ Dr. M.G.R Educational and Research Institute - University, Chennai, India. \\ ${ }^{b}$ Sustainable Power and Energy Research Centre, Dr. M.G.R Educational and Research Institute \\ Chennai, India.
}

Received 19 February 2015; Accepted 11 October 2015

\begin{abstract}
A primary and necessary focus in creating a greener environment is the conversion of existing power-generation sources to renewable power sources in the near future. Another important focus is to develop sustainable household power generation to a low-voltage electricity grid with a power purchase and selling facility. To help with achieving the above vision, the objective of this work is to critically analyze the existing low-voltage distribution system and make suggestions for restructuring it to the low-voltage interconnected microgrid (MG). The test was carried out in the Tamil Nadu Electricity Board (TNEB) 100kVA transformer feeder which was connected to supply around 100 houses with electricity. The performance analysis of the proposed system was examined through different case studies, represented as a normal operating condition of the existing distribution system and a reconstructed and interconnected MG to the TNEB grid. The project was designed and analyzed using PSCAD software. The results discussed in the project are helpful in examining the effects of multiple distributed energy resources on distributed generation. In future, knowledge of these effects may be helpful for rural area electrification.
\end{abstract}

Keywords: Distribution systems, Renewable energy, Wind, Solar, Microgrid.

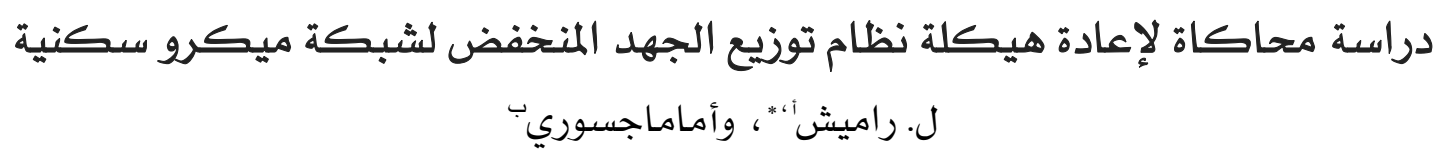

الملخص: إن أسـاس التركيز اللازم نحو بيئة خضراء هو تحويل الانتاج الحالي إلى طاقة متجددة يِّ فترة قصيرة. أها المنهجية الهامة الأخرى فتكون عن طريق تطوير انتاج منزلي مستدام مع شراء الطاقة وبيع الخدمات إلى شبكة كهريائية منخفضة الجهد. من أجل أدنى مساعدة للوصول للرؤية المذكورة أعلاه، فإن الهدف من هذا العهل هو تحليل جزء من نظام توزيع الجهد المنخفض الحالي وإعادة هيكلته إلى الجهد المنخفض لشبكة ميكرو مترابطة. تم إجراء الاختبار ِّْ مجلس كهرياء تاميل نادو لمحولات التفذية التي تم إيصالها من أجل تغذية نحو · ․ منزل. تحليل أداء النظام المقترح تم دراسته من خلال دراسات الحالة المختلفة والتي تمثل ظروف التشغيل العادية لنظام التوزيع الحالي، واعادة بناء شبكة ميكرو، وشبكة ميكرو مترابطة ، وشبكة ميكرو مترابطة مع شبكة

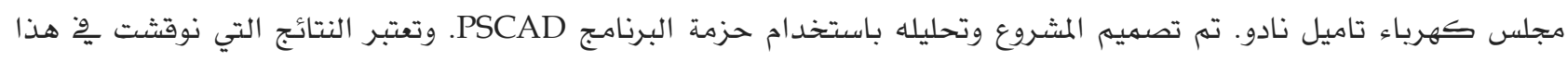

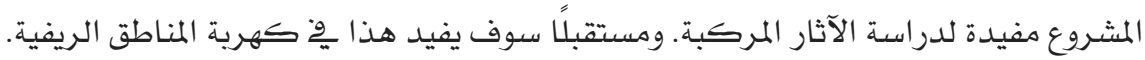
الكلمات المفتاحية: نظم التوزيع والطاقة المتجددة، الرياح، الطاقة الشهسية، شبكة ميكرو.

*Corresponding author's e-mail: lramesh@theiet.org 


\section{Introduction}

Nowadays conventional power systems face numerous problems including depletion of fuel resources, poor energy efficiency, and pollution. Thus, a new trend in generating power is introduced by using renewable, nonconventional energy sources including biogas, photovoltaic (PV) cells, combined heat and power (CHP) systems, micro turbines, and wind turbines. This type of power generation is known as distributed generation (DG) and the energy sources are distributed energy sources. Microgrids (MG) are generally attractive to consumers, and a great number of them will be installed at consumers' sites. The cluster of loads and microsources consider MGs a viable source of both power and heat for local communities. This concept also provides a new model for defining the operation of DG (Brabandere et al. 2007; Carrasco et al. 2006; Cheng et al. 2009).

A MG operates on small units of less than $100 \mathrm{~kW}$ with static electronic interfaces and low costs and low voltage but high reliability in a system that is easily placed on customer sites. The effectively designed power electronics and controllers insure that the MG can meet the needs of its customers and utilities. The best backup power for consumer sites is the installation of a MG and the interconnection of DG with an electricity grid that consists of electricity generation, energy storage and power management systems. The MG contains a combination of technologies, which provide supply-and-demand-style management and can be located near the energy center. MGs also enable a more efficient use of waste heat in CHP applications, which boosts efficiency and lowers emissions. The CHP systems provide electricity, heat for industrial processes, hot water, refrigeration, space heating and cooling and humidity control to improve indoor air quality and comfort.

Over the last few years, however, a number of influences have combined to lead to an increased interest in MGs' schemes. A MG, when operated as an autonomous systems, can cause several technical problems in its operation and control. Such technical issues presented by the present researchers are discussed here. The load sharing is possible in multiple DG units when operated in islanded mode. The frequency and voltage can be controlled through droop control to achieve power sharing in a decentralized manner (Corradini et al. 2010; Fornari et al. 2013; Guerrero et al. 2005; Guerrero et al. 2011; Gungor et al. 2011; He and Li 2011; Mohamed et al. 2009; Ramanarayanan et al. 2010). A number of methods have been proposed to solve MGs' power control issues. The new framework for the frequency-voltage and real and reactive power concept were proposed (Li et al. 2011; Mehrizi-Sani and Iravani 2010) to improve the stability of a MG system. These methods cannot suppress the reactive power of sharing errors that can be experienced when small synchronous generators are incorporated into the MG. The proper power sharing between inverter-based DG units and electric machine-based DG units are more challenging problems to be addressed. Harmonic current injection methods (Melicio et al. 2008) were used to reduce reactive and harmonic power sharing errors. Ji et al. (2014) presented a case study of a MG arranged between two commercial/residential buildings in order to overcome regulatory barriers. In the study, a load management strategy aimed at controlling power withdrawal at the point of delivery was developed. Pogaku et al. (2007) proposed a MG smart grid and presented a review of the optimal distribution models of MG in a smart grid environment, pointing out issues in the existing models. The optimal load distribution model of MG both in objective functions and constraints was established and discussed with effective output. Zhou et al. (2014) presented an optimization problem for residential MG energy management with combined cooling, heating and electricity technology. It was executed in two-stages to find the optimal installed capacity investment and operation control of CHP and cooling. The proposed approach was tested with residential area energy management in northern China. Computational results were gathered under different robustness levels and analyzed in order to provide investment decisions and operations strategies.

The aim of this work is to critically analyze part of an existing low-voltage distribution system and its restructured low-voltage interconnected MG. The study was carried out with the Tamil Nadu Electricity Board (TNEB) 100kVA transformer feeder which delivers power to 100 houses. In the following sections, this work models renewable sources, presents distribution feeders, the restructuring of residential MGs and interconnected MGs. Performance analyses were carried out for the 


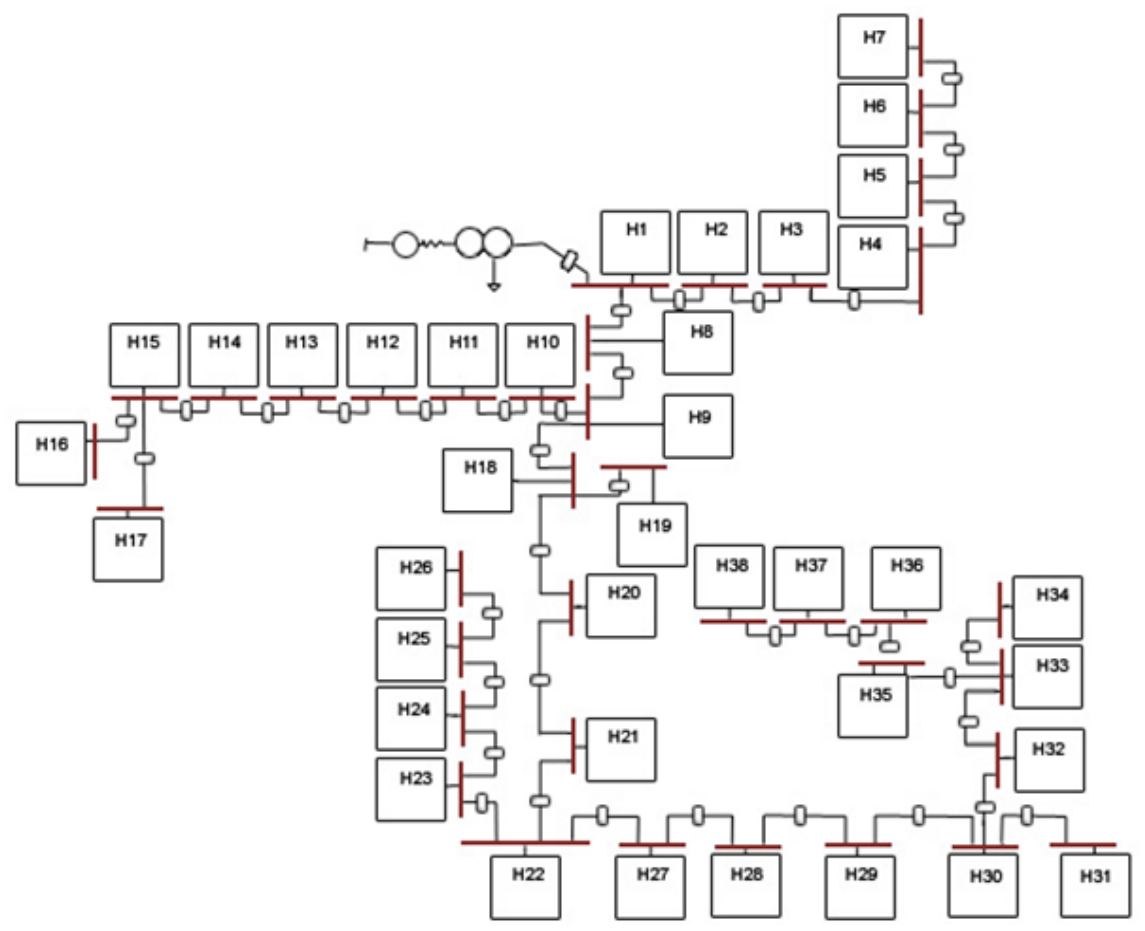

Figure 1. The PSCAD-generated layout of the Tamil Nadu Electricity Board (TNEB) distribution feeder.

proposed MG and are ready for implementation in Chennai.

\section{Modeling of Test System}

The work developed in this project was used to understand and model the electrical effects of multiple distribution resources on a distribution system. The analyzed test system was taken from the TNEB distribution system. The existing system is connected with a $100 \mathrm{kVA}$ transformer rating, which supplies power to the houses connected to this feeder. Section 2 will discuss modeling the test distribution feeder, house distribution system, and wind and solar sources.

\subsection{Modeling the TNEB Low-Voltage Distribution System}

Initial studies on this feeder were done in July 2013 at Rampoornanagar, which is in Athipet village. The test system consists of three feeders running between the 100kVA transformer and 40 houses, including single, double, triple and bungalow type houses. The layout, generated with PSCAD software (Electrotek Concepts, Inc., Beverly, Massachusetts, USA) and data drawn from the TNEB Power Engineers' Handbook (2010), is modeled in Fig. 1.

\subsection{Modeling the Home Distribution System}

The distribution layout of the houses was reconstructed according to a limited number of nodes in order to reduce complexity without affecting the respective loads. The breaker box was considered the bus and all loads were chosen based on resistive, inductive, or capacitive capabilities. The lumped load component in the PSCAD was considered in this analysis so as to change the $\mathrm{R}, \mathrm{L}$, and $\mathrm{C}$ components for the load. The sample model of the PSCAD layout is shown in Figs. 2-3.

The selected houses were also supplied with renewable resources, in this case wind and solar sources which are ideal in Chennai's climate. Modeling wind and solar sources with PSCAD is described in the section below.

\subsection{Modeling Renewable Sources}

Wind turbines convert wind energy to electrical energy for distribution. Aerodynamic modeling helps determine the optimum tower height, control systems, number of blades, and blade shape. Wind turbines are generally divided depending on their axis of rotation (ie. horizontal or vertical axis), with the horizontal axis type always providing better performance.

Of the wind turbine costs, $20 \%$ includes the blade for converting wind energy to low speed 


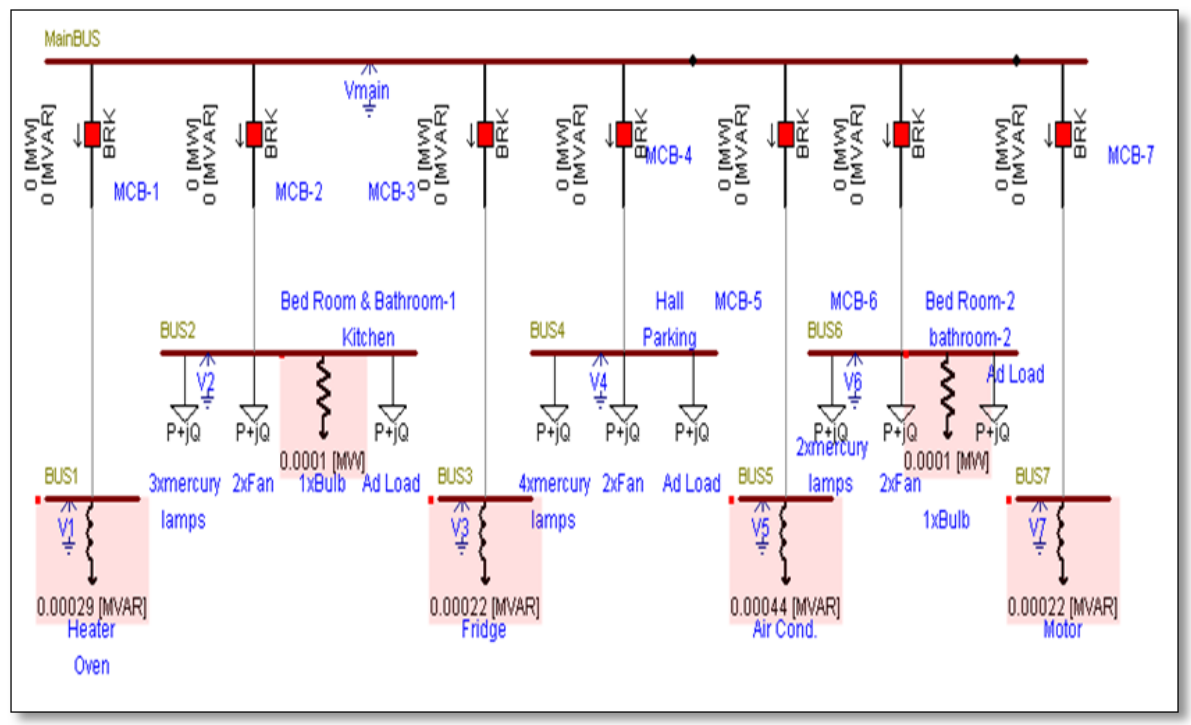

Figure 2. Single-bedroom house layout.

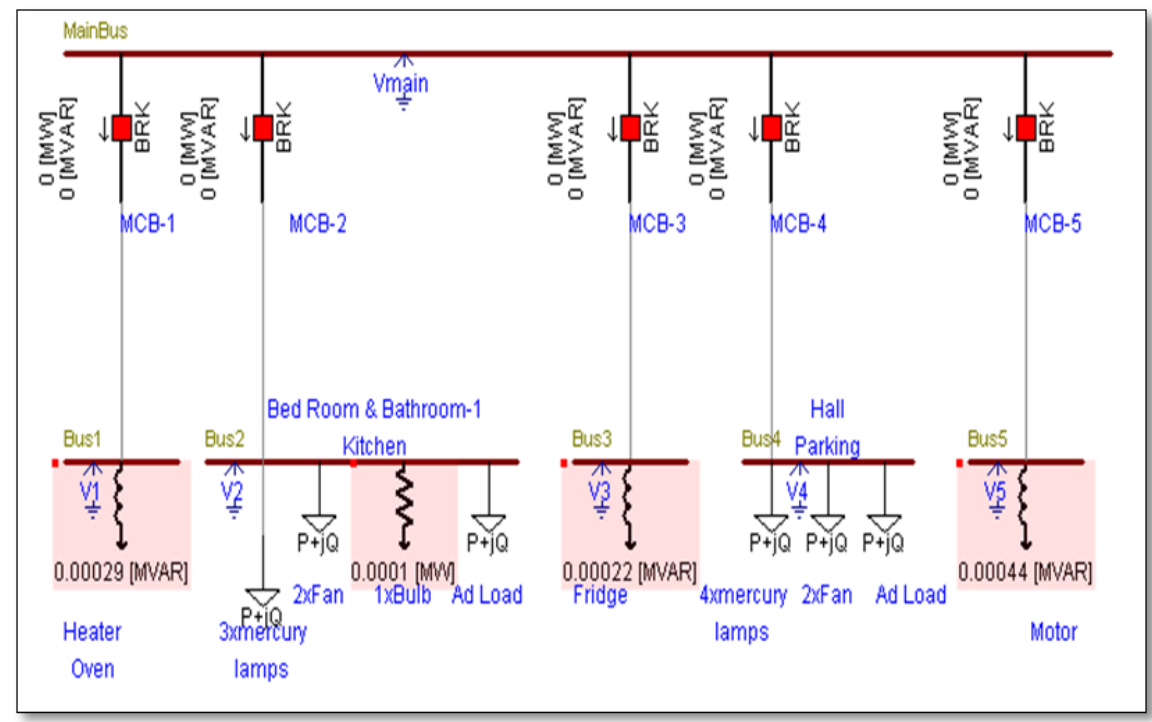

Figure 3. Double bedroom house layout.

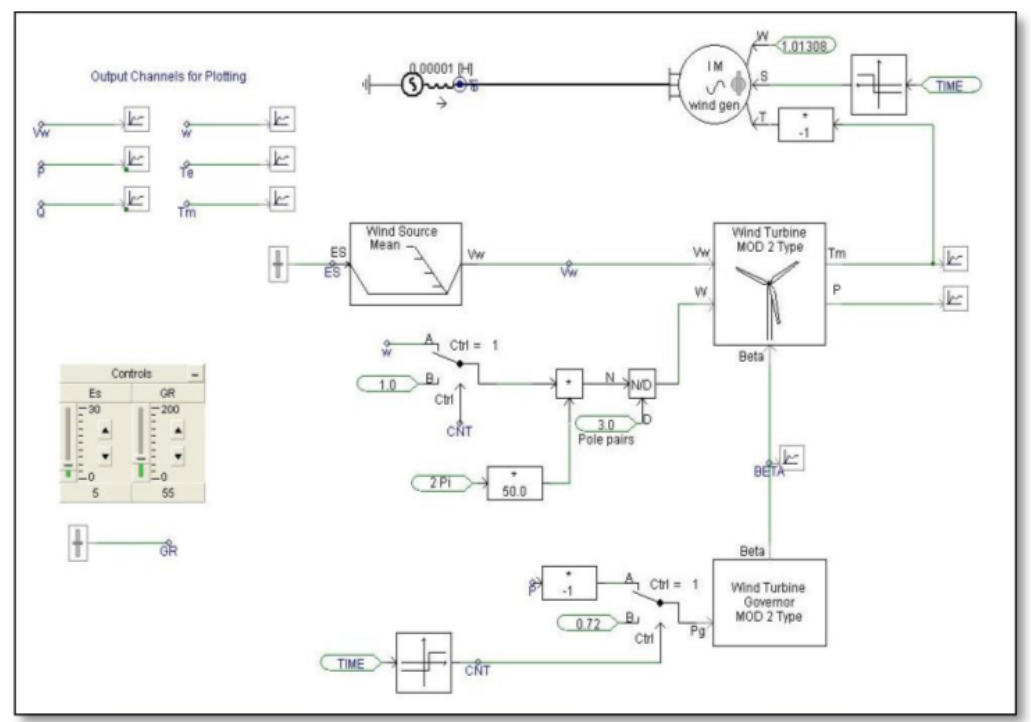

Figure 4. PSCAD wind turbine model. 


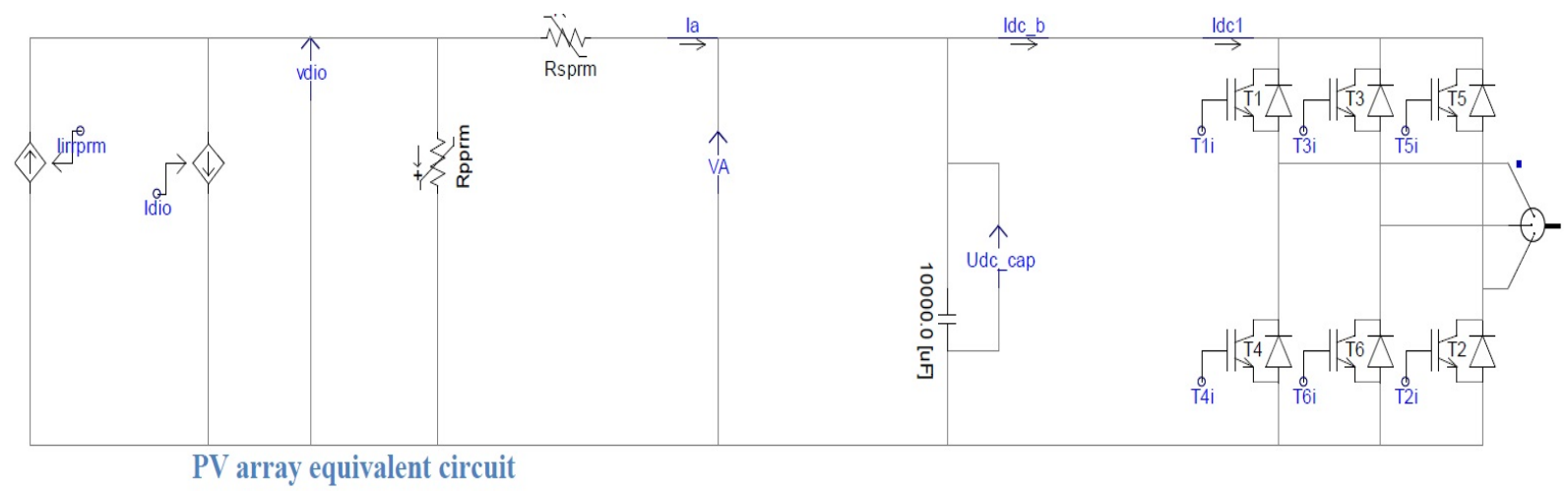

Figure 5. A simulated solar model where anti-islanding schemes were not implemented.
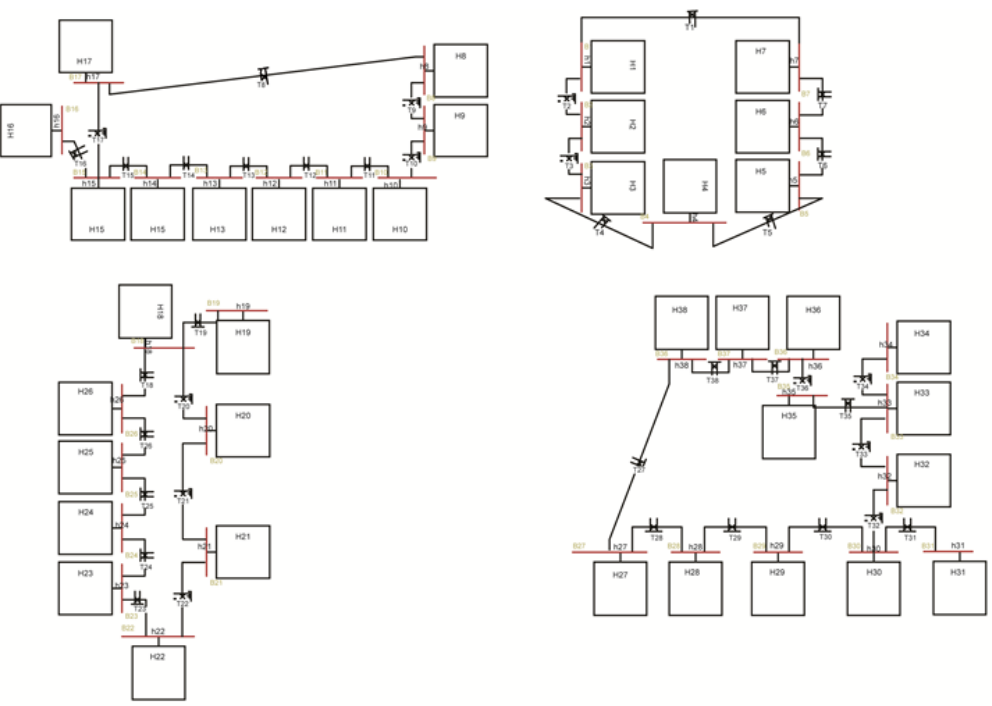

Figure 6. Layout of reconstructed MG system into four sub-systems.

rotational energy, $45 \%$ includes the electrical generator and $12 \%$ includes the control electronics and gearbox. The remaining $23 \%$ of the wind turbine cost includes the tower, land, foundation, road and installation. The PSCAD models of the wind turbine generator connections are shown in Fig. 4.

A photovoltaic (PV) cell is an array that carries solar voltaic material that changes solar energy into electrical energy. It includes multiple mechanical and electrical engineering components. The materials used in PVs include mono-, poly-, and micro-crystalline silicon, cadmium telluride, and copper indium selenide. The DC power output at the PV device terminals can be directly used to switch on small loads like lighting systems or small DC motors. Maximum power from a PV array is possible through maximum power point tracking technology. To integrate the PV cell into an alternating current (AC) system, the inverter model is connected at the output of the cell, and the DC source for the currentcontrolled inverter is fed from the PV source. Figure 5 shows a simulation model with the inverter model when anti-islanding schemes were not implemented.

\subsection{Modeling MGs}

The restructuring of the present system was formulated based on a performance analysis of the system and the present customers' willingness to embrace renewable power. House numbers $2,4,8,10,14,20,24,26,28,32$, and 34 used renewable power through solar and wind. After the survey study with existing customers, it was decided to convert the present system into four sub-systems.

Assumptions were made that $50 \%$ of the total maximum loads would go for transition to the renewable power. In reference to above, the optimal planning and location of renewable sources were identified and placed for simulation. Figure 6 shows PSCAD MG layout. 


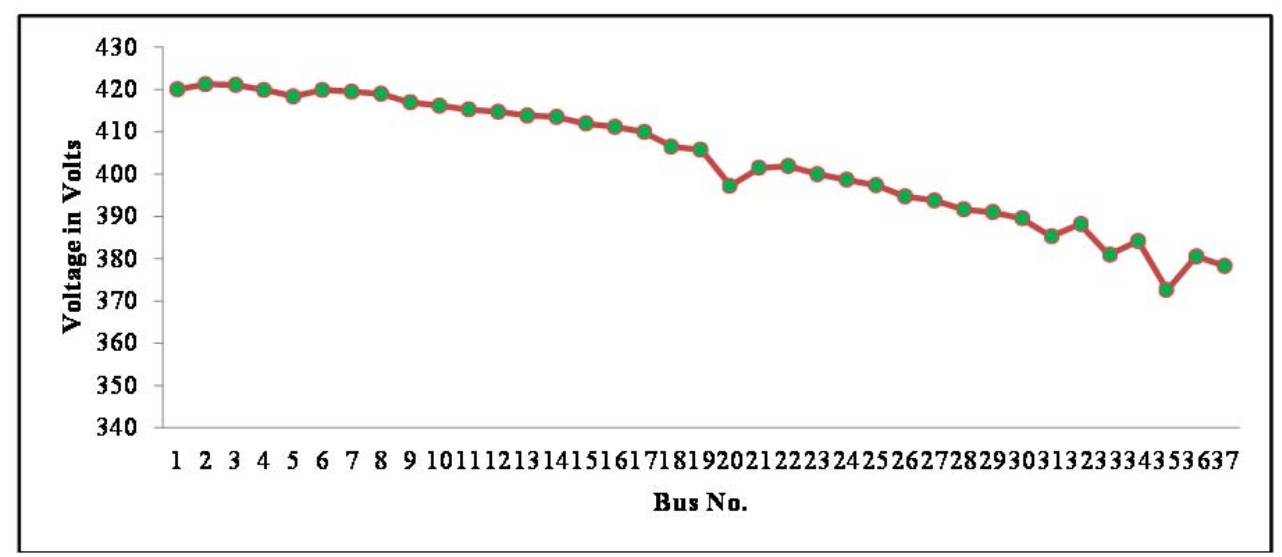

Figure 7. Voltage characteristics of the existing distribution system showing that the tail end customer receives lower voltage than the customers at the beginning of the system.

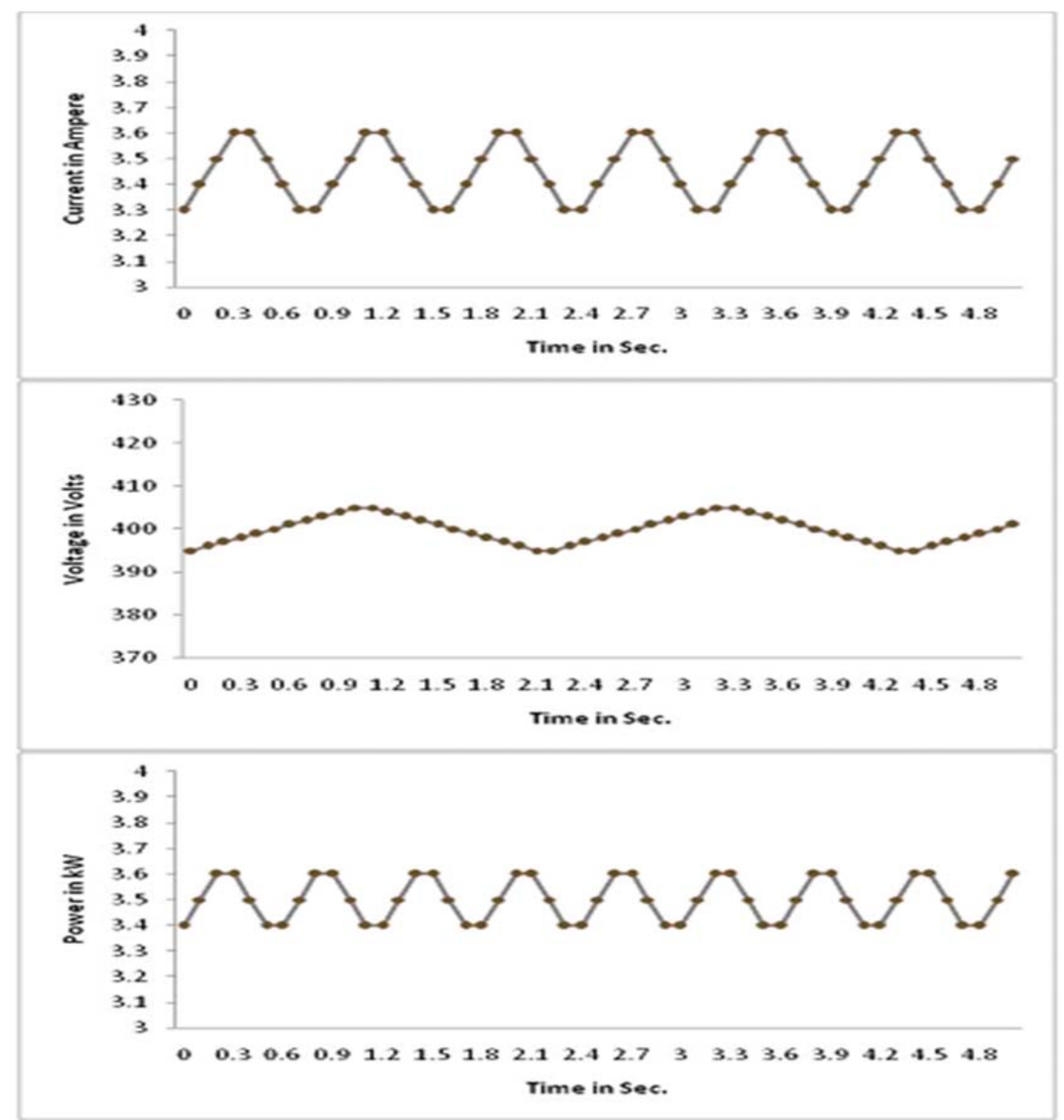

Figure 8. House seven's power characteristics.

\section{Simulated Results}

After designing the model, it was simulated with various parameters and the grid capability was assessed. In the designed model, there were different types of houses which were also being supplied with power from renewable resources like wind and solar. The impact of the designed 
model with renewable resources is investigated in the following case studies.

Three different case studies were carried out to analyze the performance of the designed model. The cases are as below:

- Normal operating conditions of the existing distribution system,

- The present system reconstructed into a MG system, and,

- An interconnected MG sub-system.

\subsection{Normal Operating condition of the Existing Distribution System.}

To evaluate the normal operating condition of the existing distribution system, the present system with a normal operating load was considered for analysis. In this condition, the houses are simply supplied with power from a grid supply. The existing distribution system was designed and evaluated to verify the performance of the system. The representation of bus voltage with respect to the bus number (Fig. 7) shows that the tail end customer receives lower voltage than the initial customers.

From Fig. 7, it can be concluded that there is a gradual decrease in voltage at the tail end of the system, implying that the system performance also gradually reduces. This implementation for renewable resources is that such a system will improve performance. The graphic results for houses seven and 38 show a gradual decrease in voltage which will impact the quality of power (Figs. 8 and 9).

The above graph shows the real reactive power characteristics of house seven. From the graph, it is clear that the performance is reduced when compared with the transformer characteristics, and especially the power curves.

The above graph shows the real reactive power characteristics of house 38. From the graph, it is clear that the performance is reduced when compared with the transformer characteristics. The VI-characteristics and the power curves become more oscillatory as a result of the reduction in the voltage profile to $25 \%$.

\subsection{The Present system restructured into a MG System}

The present system restructured into four sub-systems connected through renewable power generation is called a residential MG. Each subsystem operates with its own renewable power sources connected through the different houses. The voltage output of the subsystems with respect to bus number is represented in Figs. 10-13.

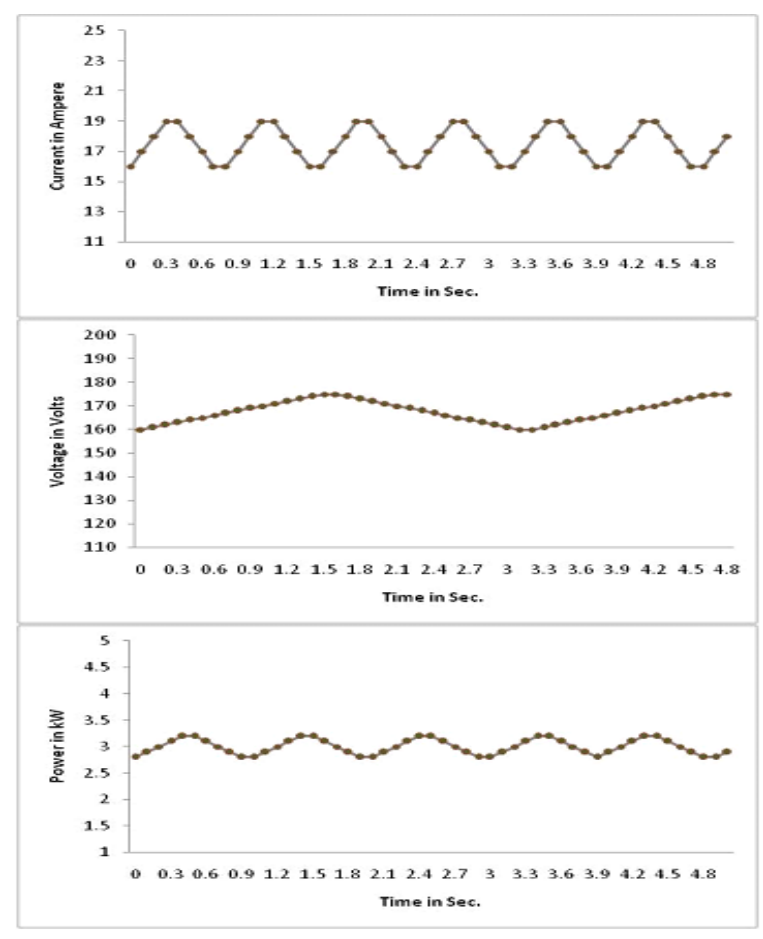

Figure 9. House 38's characteristics. 


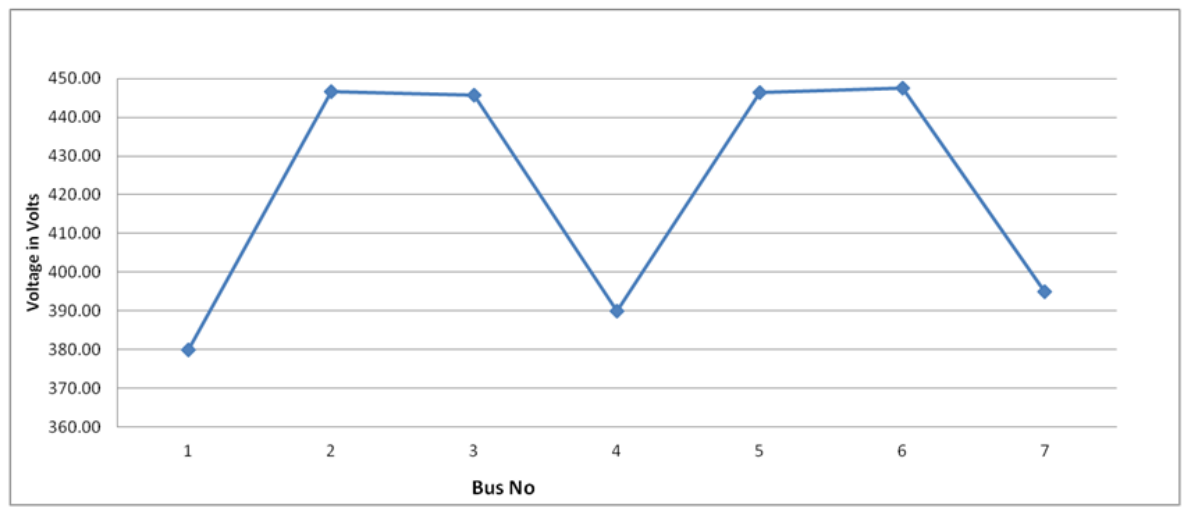

Figure 10. Voltage characteristics of subsystem one.

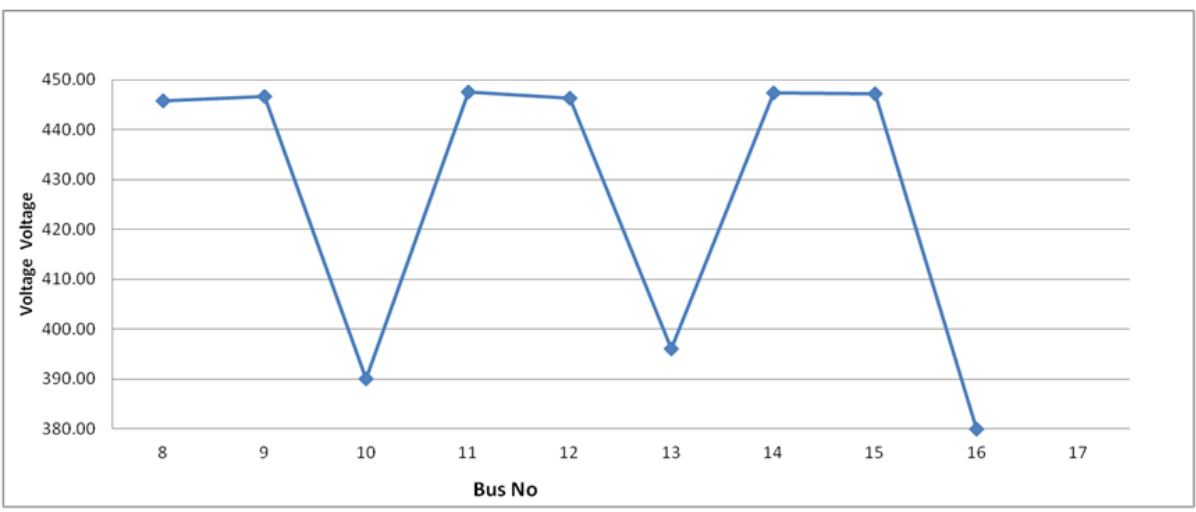

Figure 11. Voltage characteristics of sub-system two.

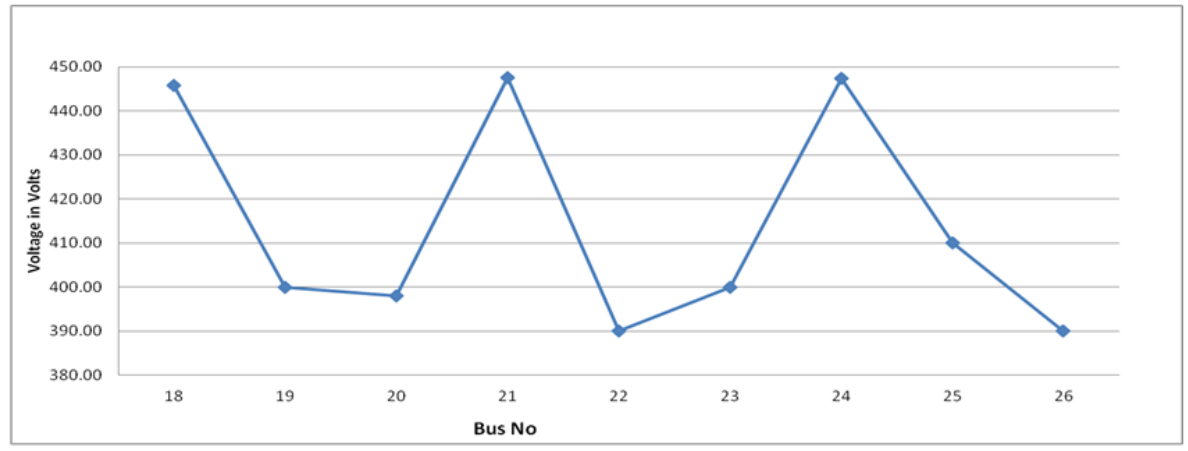

Figure 12. Voltage characteristics of sub-system three.

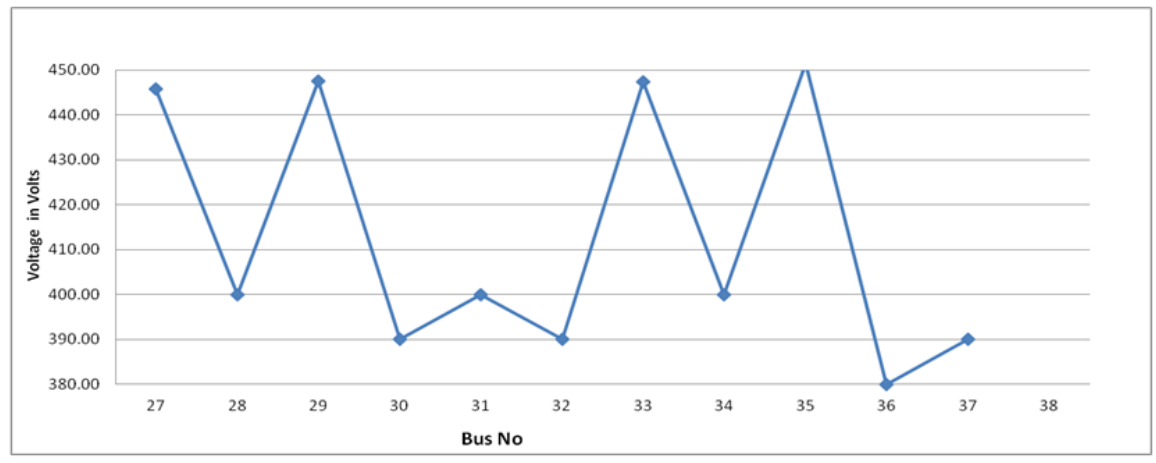

Figure 13. Voltage characteristics of sub-system four. 
From the above graphs, it can be observed that the proposed system will be able to deliver power under normal load conditions. Each graph indicates an increase and decrease in voltage between 390 and 440 volts, indicating that houses with renewable power have good voltage profiles. The PSCAD output of the sample house is expressed in Figs. 14 and 15.

From the above results, it can be observed that the voltage performance is maintained at 440 under a sudden change in load. The limitation of the above system is that only $20 \%$ of the houses had voltage profiles of 400 volts. To improve the voltage performance to 440 volts at all the buses, the sub-systems should be interconnected with the main grid, as is discussed in next section.

\subsection{An interconnected MG Sub-System}

In the case of an interconnected MG subsystem, the interconnections of all of the MGs are connected with the help of a breaker. By making this connection, the power among each sub-system MG can be managed; thus, in case of power failure, they can receive power through another DG. The interconnected MG is shown in Fig. 16.

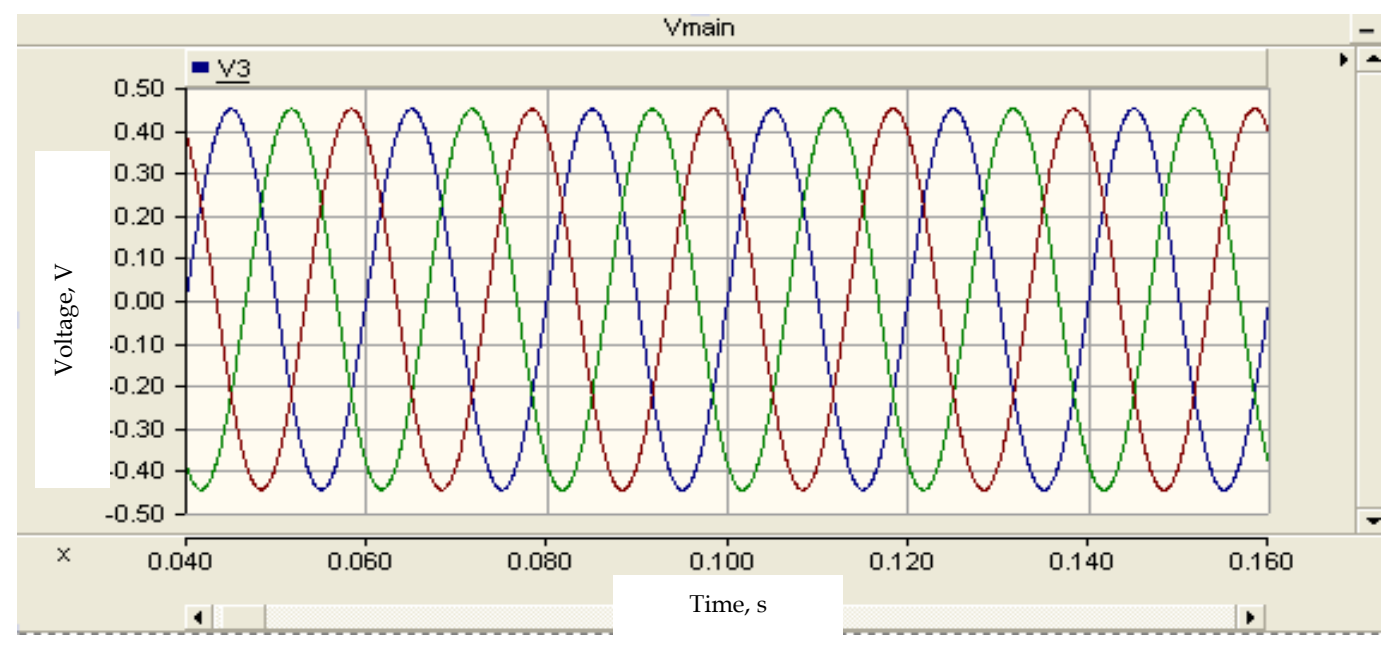

Figure 14. House three's voltage characteristics.

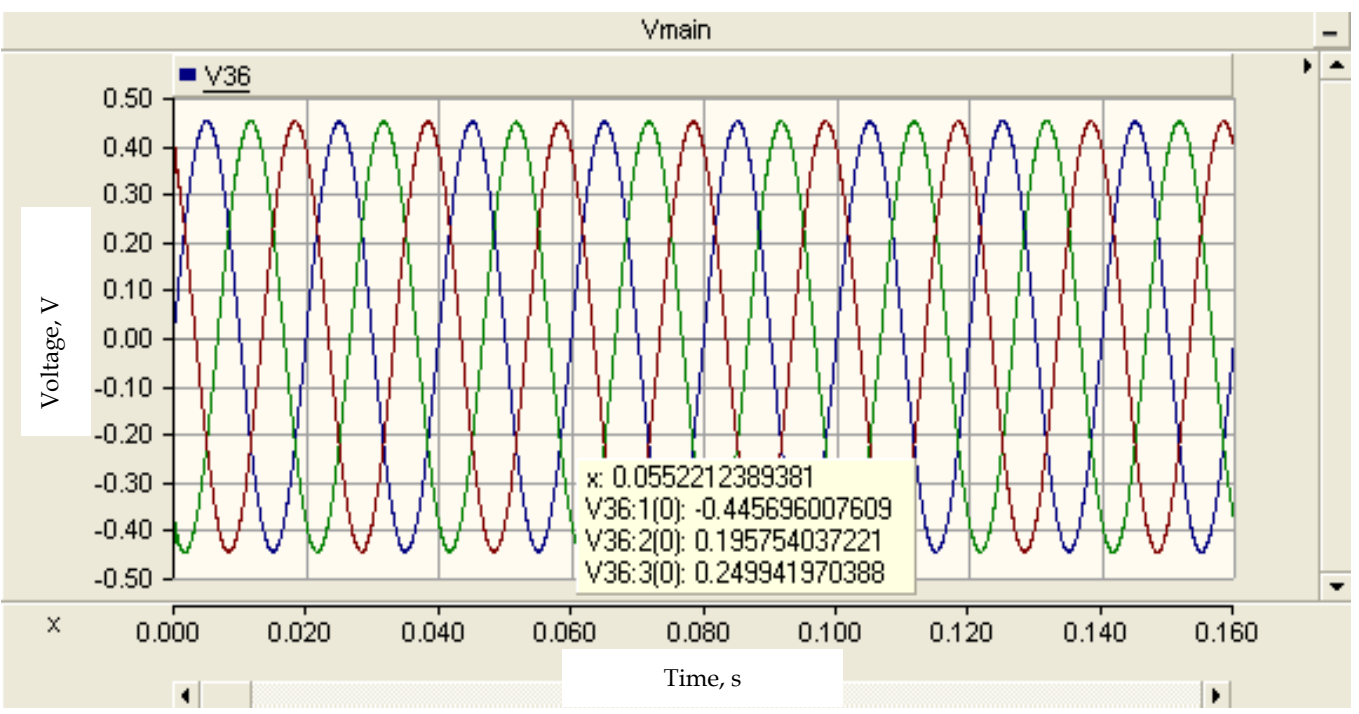

Figure 15. House 36's voltage characteristics. 


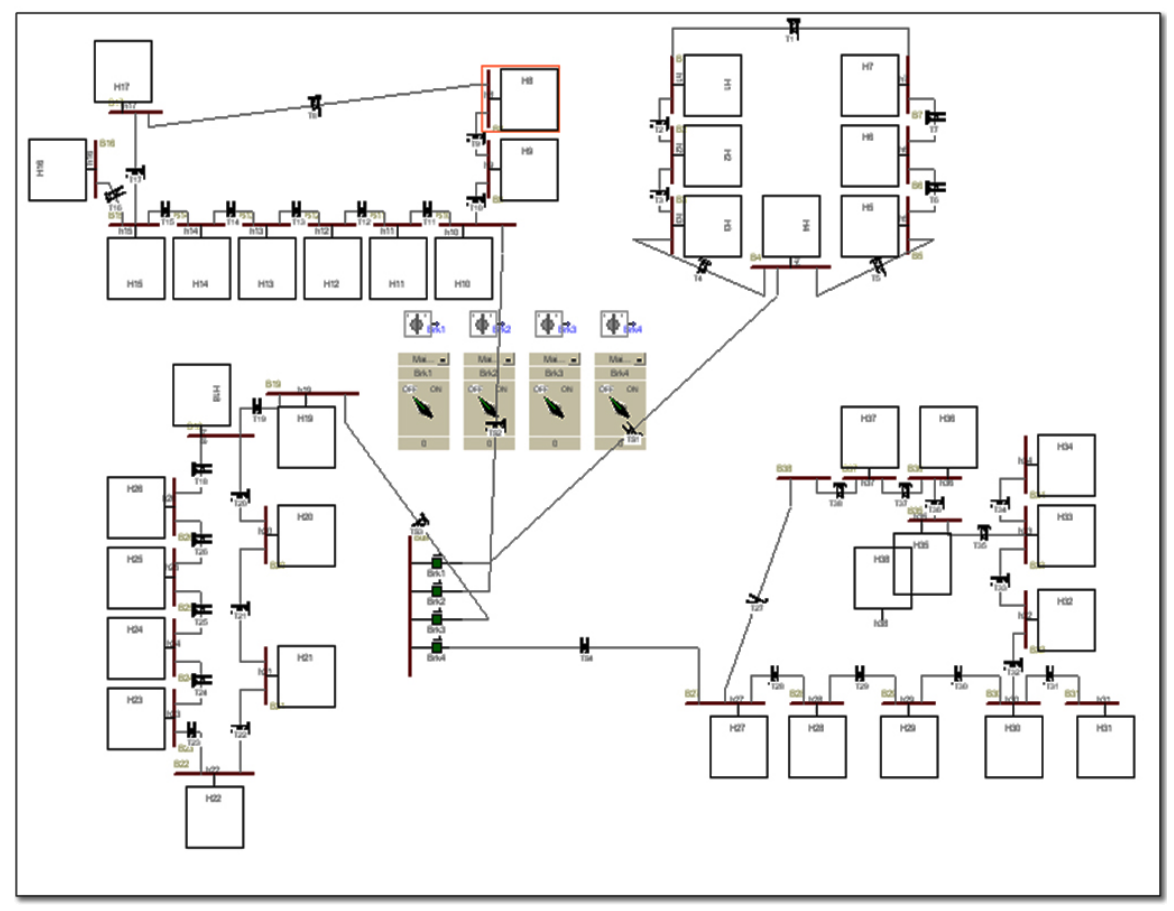

Figure 16. Interconnected MG layout.

The above restructured MG layout was executed in PSCAD in different cases, including in the case of opening/closing the breaker, thereby checking the performance of the system. By doing this, the supply can be shared throughout the network. In such a case, even if there is a failure in any part of the network, the entire system will be supplied.
The comparison of the existing and proposed system is shown in Fig. 17. It can be observed that an interconnected MG will provide better performance when compared with independent systems. The MG will provide stable, good quality power throughout the system, all the way to the tail end.

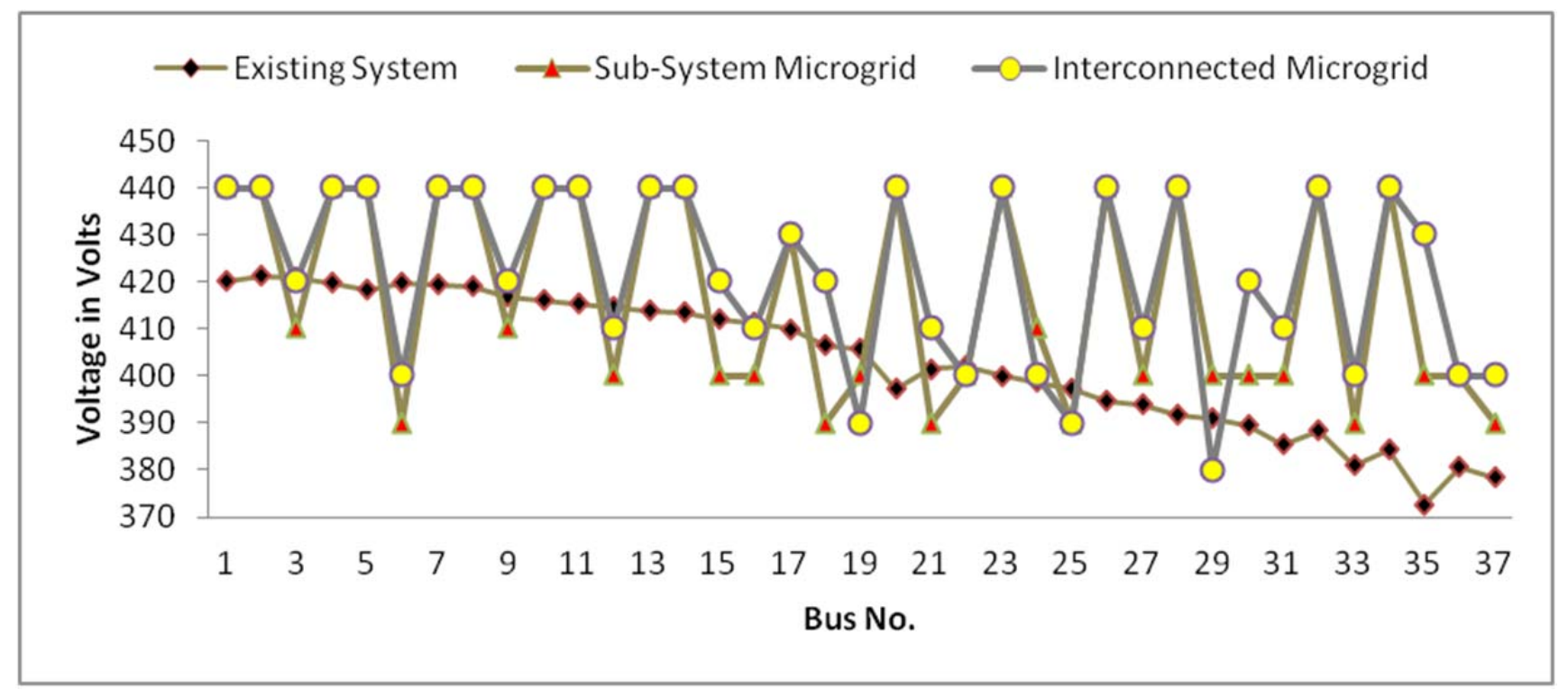

Figure 17. Comparison of the existing and proposed MG. 


\subsection{Discussion}

The existing and proposed feeders were simulated and analyses of bus voltage in all the cases are shown in previous figures. The existing bus voltage varies from $370-420 \mathrm{~V}$, with a PSCAD voltage regulation of $16 \%$. The practical voltage regulation was measured at $23 \%$. The bus voltage of the restructured MGs varies from $400-440 \mathrm{~V}$, with sustainable power throughout the system. The voltage in bus numbers 2, 4, 8, 10, 14, 20, 24, 26, 28, 32 and 34 was maintained at $440 \mathrm{~V}$, clearly indicating that the DGs are connected at these buses in the houses. The case study analysis and the tail end $5 \%$ voltage regulation show that the proposed system is of a high accuracy. Due to space limitations, results of the case study on a sudden drop or increase in load and various fault conditions are not reported. However, the case study shows that the system would be able to handle such a situation, resulting in better voltage on the bus. The proposed system was recommended to the customers for implementation in April 2015.

\section{Conclusion}

The present necessity of energy saving through a restructured MG is discussed in this paper. The local generation of renewable power and the interconnection between MGs may be a green solution for the issue of an energy shortage. The team, after performing a local survey with the customers, identified a distribution feeder for conversion to four local grids (MG1, MG2, MG3 and MG4). The proposed isolated and interconnected MGs were tested through case studies. The output predicted that the proposed system will work well even through interrupted faults. The customers agreed to implement the restructured MG feeders for effective operation and energy savings. The cost analysis for implementation will be reported in future work.

\section{References}

Brabandere B, Bolsens JVD, Keybus A, Woyte J, Drisen, Belmans R (2007), A voltage and frequency droop control method for parallel inverters. IEEE Transactions on Power Electronics 22(4): 1107-1115.

Carrasco LG, Franquelo IT, Bialasiewicz E, Galvan RCP, Guisado AM, Prats, Leon J,
Moreno-Alfonso N (2006), Power-electronic systems for the grid integration of renewable energy sources: A survey. IEEE Transactions on Industrial Electronics 53: 1002-1016.

Cheng PT, Chen CA, Lee TL, Kuo SY (2009), A cooperative imbalance compensation method for distributed generation interface converters. IEEE Transactions on Industrial Applications 45(2): 805-815.

Corradini L, Mattavelli P, Corradin M, Polo F (2010), Analysis of parallel operation of uninterruptible power supplies though long wiring cables. IEEE Transactions on Power Electronics 25(4): 2806-2816.

Fornari S, Di Giorgio A, Liberati F (2013), A case study of a commercial/residential MG integrating cogeneration and electrical local users. 12 ${ }^{\text {th }}$ International Conference Environment and Electrical Engineering (EEEIC) 363-368.

Guerrero JM, de Vicuña LG, Matas J, Castilla M, Miret J (2005), Output impedance design of parallel-connected UPS inverters with wireless load sharing control. IEEE Transactions on Industrial Electronics 52(4): 1126-1135.

Guerrero JM, Vasque JC, Matas J, de Vicuña LG, Castilla M (2011), Hierarchical control of droop-controlled AC and DC MGs-A general approach toward standardization. IEEE Transactions on Industrial Electronics 55(1): 158-172.

Gungor VC, Sahin D, Kocak T, Ergut S, Buccella C, Cecati C, Hancke GP (2011), Smart grid technologies: Communications technologies and standards. IEEE Trans. Industrial Information 7(4): 529-539.

He J, Li YW (2011), An accurate reactive power sharing control strategy for DG units in a MG. in Proceedings from the 8th International Conference on Power Electronics and ECCE Asia, Jeju, Korea 551-556.

Ji L, Niu DX, Huang GH (2014), An inexact two-stage stochastic robust programming for residential micro-grid management-based on random demand. Elsevier Energy 67(1): 186199.

Li W, Li YW (2011), Power management of inverter interfaced autonomous MG based on virtual frequency-voltage frame. IEEE Transactions on Smart Grid, 2(1): 30-40.

Mehrizi-Sani A, Iravani R (2010), Potentialfunction based control of a MG in islanded and grid-connected modes. IEEE Transactions on Power Systems 25(4): 1883-1891. 
Melicio R, Mendes VMF, Catalão JPS (2008), Wind energy systems and power quality: Matrix versus two level converters. In Proceedings of the International Conference on Renewable Energy and Power Quality, Santander, Spain.

Mohamed F (2006), MG modeling and simulation. Thesis report - Helsinki University of Technology Control Engineering Laboratory.

Pogaku N, Prodanovic M, Green T (2007), Modeling, analysis and testing of autonomous operation of an inverter-based MG. IEEE
Trans. on Power Electronics 22(2): 613-625.

Ramanarayanan V (2010), Decentralized parallel operation of inverters sharing unbalanced and nonlinear loads. IEEE Transactions on Power Electronics 25(12): 3015-3025.

TNEB Engineers' Association (2008), Power Engineer's Handbook, $6^{\text {th }}$ ed., Chennai, India: Allied Publishers.

Zhou KL, Yang SL, Chen ZQ, Ding SA (2014), Optimal load distribution model of microgrid in the smart grid environment. Elsevier Renewable and Sustainable Energy Reviews 35: 304-310. 